\title{
Thoracic Lymph Node
}

National Cancer Institute

\section{Source}

National Cancer Institute. Thoracic Lymph Node. NCI Thesaurus. Code C33769.

Lymph node located in the thoracic cavity. 